\title{
AIR EXCHANGE RATE IN AIR QUALITY ASSURANCE - A CASE STUDY
}

\author{
I. L. Cîrstolovean ${ }^{a}$ *, M. Horneț ${ }^{a}$, Ana Diana Ancas ${ }^{b}$, M. Profire ${ }^{b}$ \\ a‘Transilvania’University Brasov, Faculty of Buildings Engineering, Brasov, Romania, e-mail: ioan.cirstolovean@ unitbv.ro \\ b Technical University “Gh. Asachi” Iasi, Faculty Buildings Engineering and Buildings Services, Iasi, Romania, \\ e-mail: ancas05@yahoo.com
}

Received: 20.02.2018 / Accepted: 28.02.2018 / Revised: 21.03.2018 / Available online: 31.05.2018

DOI: $10.2478 /$ jaes-2018-0002

KEY WORDS: ventilation rate, thermal load, indoor temperature, measurements.

\begin{abstract}
:
The goals of this paper are to estimate some parameters - indoor temperature and ventilation rate - necessary to determine the heat load demand for ventilation in the amphitheatre named 'A TALPOSI'-Faculty of Buildings Engineering- with a number of at the most 120 occupants. The study presented in this paper is made when in the amphitheatre it is necessary to assure a comfortable temperature by a permanent functioning of the heating system. The number of air exchanges necessary in the amphitheatre in the natural ventilation process, more exactly, to assure a minimum air exchanges, is imposed by the requirements for the assurance of physiologic comfort in the amphitheatre for the time interval when it is occupied by students. The inner air debit should cover the harmful emissions in the amphitheatre. By the help of these calculated (measured) parameters we have calculated the heat load for ventilation. In the end, with the data obtained from calculations and measurements we find ourselves in the situation of establishing the size of the heat exchanger corresponding to the room, to heat the fresh air taken from outside and send it inside the amphitheatre. The measurements are made with the TESTO apparatus of the faculty. The minimum requirements to assure the thermal comfort are: to achieve a minimum internal temperature $\theta \mathrm{i}(\mathrm{t})$ higher than (or equal to) the normal indoor temperature associated to this space and to assure the air quality, the air exchange rate. The authors want to highlight by this study the necessity and importance of the control on the number of air exchanges in rooms with a high number of occupants and overall, the control of the fresh air debits. The fact that the focus is more and more on heat loss cuts in rooms by tightening closing elements gives birth to the necessity of control of the ventilation system with effects on the consumption of mechanical energy.
\end{abstract}

\section{INTRODUCTION}

The air quality from inside the buildings is one of the major ecological problems in Europe because $60-90 \%$ of our life is spent in buildings. The indoor air quality is very important for the health of population, the more so in case of students who spend most of their time in classrooms, amphitheatres, and libraries (Catalina, T., \& Iordache, V., 2012), (Bernardi N., \& Kowaltowski D.C.C.K., 2006). The indoor air quality has an influence on occupants' health and on their activity efficiency.

The parameters of indoor air, temperature, level of acoustic pressure, lighting level together with the age of occupants, gender, level of education and the activity contribute to their comfort (Huang, Y. C.et al,2013), (Coley D.A et al ,2007).

The European standard EN 7730 ISO, 2005 aims at using the predicted mean vote (PMV) and predicted percentage of dissatisfied (PPD) indices to evaluate the quality of indoor air in buildings. The improper living conditions because of interior environment determine an increase in living cost compared to the cost of energy consumed to assure living conditions (Sârbu I., \& Sebarchievici C. ,2013), ( Santamouris M et al, 2006).

The energy consumption of buildings is closely related to how they are exploited. The values set for the calculation of the indoor environment quality indices must lead to efficient energy consumption, efficient ventilation and air conditioning.

Normative acts (Assessment of indoor air quality and thermal comfort in Portuguese secondary classrooms: Methodology and results) indicate values for comfort parameters lower than those required by occupants and the energy efficiency of installations in customized microclimate buildings is higher (Toftum J. 2010).

The energy consumption of buildings increases when the mechanical ventilation and air conditioning system are used (Energy Information Administration, State Energy Data Report, 1995). To reduce the energy consumption in buildings when

\footnotetext{
* Corresponding author: Ioan Lucian Cîrstolovean, e-mail: ioan.cirstolovean @unitbv.ro
} 
ventilation is required, if we make a natural ventilation first, the energy consumption decreases by $40 \%$ (Busch J.F., 1992).

Comfort is the well-being of the occupants. Introducing fresh air into the rooms we get superior comfort conditions comparative with the closed rooms (Dascalaki E.,Santamouris M.,et. al.,1995), (Dascalaki E. G, Sermpetzoglou V.G, 2011).

Closed rooms do not allow the opening of windows or outdoor grille sand the indoor temperature varies within much larger limits. The air flow taken from the outside in the case of natural ventilation is determined by two factors: the climate conditions and the thermal-technical and geometric characteristics of the buildings (Chen, Q., 2009).

European Union Directive 31/2010 of the European Union has the main objective to increase the energy performance of buildings and, furthermore, it sets the minimum energy performance conditions in Article 4.

In this paper we intend to evaluate the parameters - indoor temperature and the ventilation rate- essential in determining the heat demand for ventilation with assurance of the microclimate conditions. The measurements were made with the TESTO device from the faculty in the amphitheatre 'A.TALPOSI', with a maximum capacity of 120 pers. The study presented in this paper is made when in the amphitheatre it is necessary to assure a comfortable temperature by a permanent functioning of the heating system. The number of air exchanges (air exchange rate) necessary in the amphitheatre in the natural ventilation process, more exactly, to assure a minimum air exchanges, is imposed by the requirements for the assurance of physiologic comfort in the amphitheatre for the time interval when it is occupied by students. The inner air debit should cover the harmful emissions in the amphitheatre.

The minimum conditions that must be fulfilled at the same time are:

- Achieving a minimum indoor temperature $\theta i(t)$ in amphitheatre. - Achieving indoor air quality with reference to the air exchanges rate.

\section{MATERIALS AND METHODS}

The location for experimental researches is the amphitheatre 'A TALPOSI' with 120 seats, belonging to Transilvania University of Brasov, Romania. For reasons imposed by the existing glazing facade and the aesthetics of the building, only 4 grilles for ventilation were installed. The air intake grilles are in the glazed exterior longitudinal facade and only 2 turrets for air exhaust were installed with dimensions $1.00 \times 1.00 \times 1.50 \mathrm{~m}$.

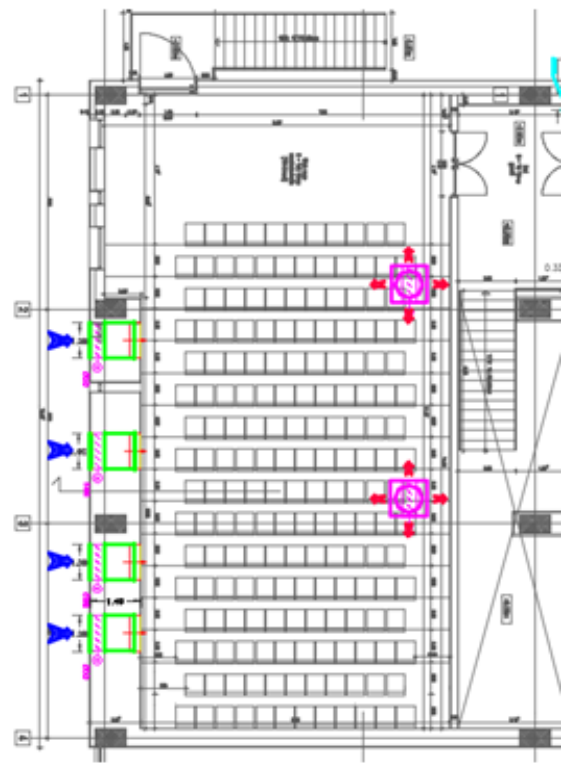

Figure 1. Locations of the grilles for supplying fresh air, and Turrets for exhaust air

To perform the measurements a TESTO data recording system was used (Figures 2-4).

The system for operating the air supply grilles and the turrets for the exhaust air has been designed and installed in the amphitheatre. The system is commanded by 3 sensors: 2 indoor sensors and 1 outdoor sensor. Indoor sensors monitor indoor air temperature and $\mathrm{CO}_{2}$ concentration. The outdoor sensor monitors the outdoor air temperature. The grilles are open until the minimum set values for indoor air temperature and $\mathrm{CO}_{2}$ concentration are achieved.

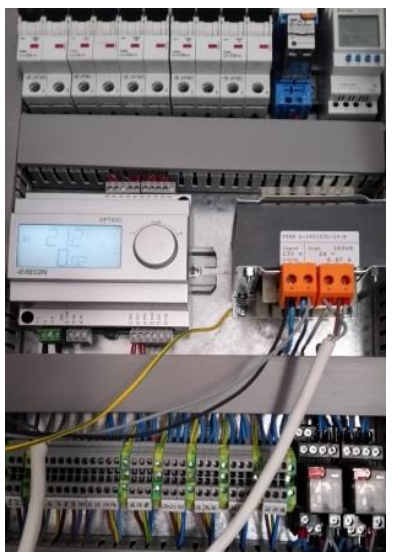

Figure 2. Electric panel 


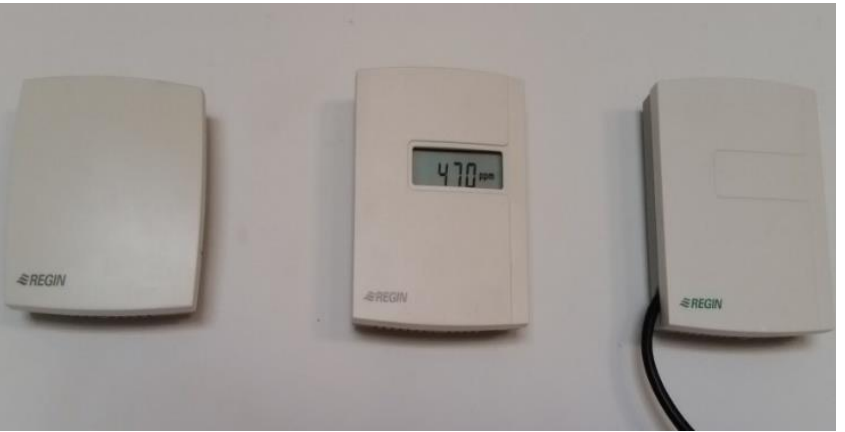

Figure 3. Interior drive sensors of the natural ventilation system

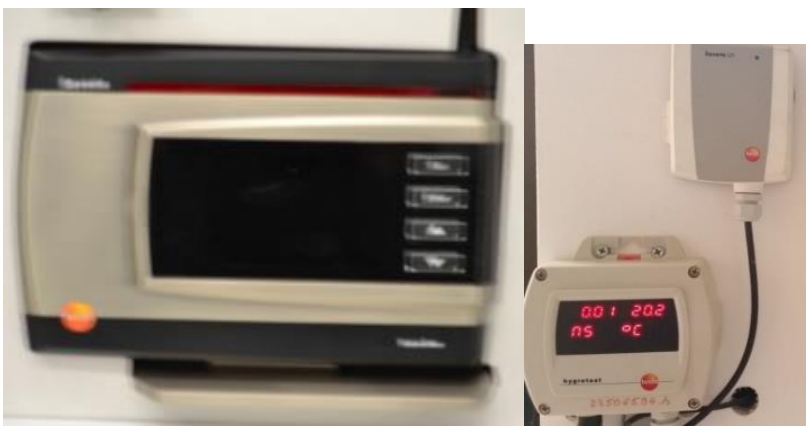

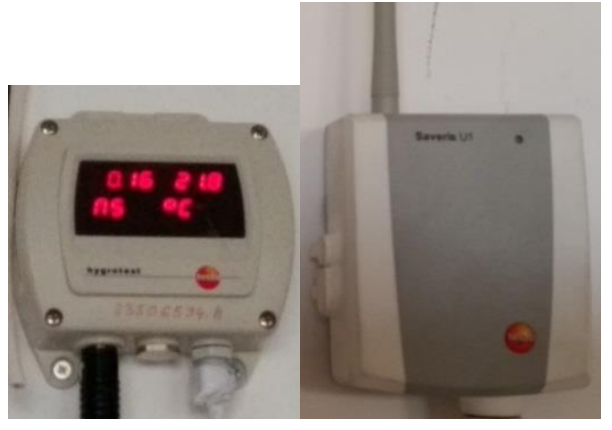

Figure 4. The central unit and the sensors of the system for recording measured data

For the day when we made the measurements the amphitheatre was occupied throughout the interval 9.30-14.00. The values obtained through measurements in the interval 9.30-14.00 are presented in Table 1.

Table 1. Parameters measured in the amphitheatre with the TESTO device in the hourly interval 9.30-14.00

\begin{tabular}{|c|c|c|c|c|c|}
\hline Time & External Temp & Air velocity & Indoor Temp & Humidity & $\mathrm{CO} 2$ Concentration \\
\hline hour & {$\left[{ }^{\circ} \mathrm{C}\right]$} & $\mathrm{m} / \mathrm{s}$ & {$\left[{ }^{\circ} \mathrm{C}\right]$} & {$[\% \mathrm{rH}]$} & {$[\mathrm{g} / \mathrm{m} 3]$} \\
\hline 9:30:00 & 14 & 0.3 & 18 & 40.2 & 5.6 \\
\hline 9:45:00 & 14.8 & 0.31 & 18.2 & 40.4 & 5.3 \\
\hline 10:00:00 & 14.7 & 0.32 & 18.3 & 40.9 & 5.3 \\
\hline 10:15:00 & 14.7 & 0.31 & 18.4 & 41.2 & 5.3 \\
\hline 10:30:00 & 14.6 & 0.3 & 18.4 & 41.5 & 5.3 \\
\hline $10: 45: 00$ & 14.6 & 0.31 & 18.5 & 41.5 & 5.2 \\
\hline 11:00:00 & 14.6 & 0.32 & 18.4 & 41.4 & 5.2 \\
\hline 11:15:00 & 14.6 & 0.28 & 18.5 & 41.5 & 5.2 \\
\hline 11:30:00 & 14.6 & 0.29 & 18.5 & 41.6 & 5.3 \\
\hline 11:45:00 & 14.7 & 0.3 & 18.4 & 41.8 & 5.3 \\
\hline 12:00:00 & 14.7 & 0.29 & 18.5 & 41.8 & 5.3 \\
\hline $12: 15: 00$ & 14.8 & 0.3 & 18.4 & 41.7 & 5.3 \\
\hline 12:30:00 & 14.8 & 0.29 & 18.5 & 41.7 & 5.3 \\
\hline $12: 45: 00$ & 14.9 & 0.29 & 18.5 & 41.5 & 5.3 \\
\hline 13:00:00 & 14.9 & 0.3 & 18.6 & 41.5 & 5.3 \\
\hline 13:15:00 & 15 & 0.31 & 18.5 & 41.4 & 5.3 \\
\hline 13:30:00 & 15 & 0.3 & 18.5 & 41.5 & 5.3 \\
\hline $13: 45: 00$ & 15.1 & 0.29 & 18 & 41.5 & 5.3 \\
\hline 14:00:00 & 15.1 & 0.28 & 18 & 41.6 & 5.4 \\
\hline
\end{tabular}


The heat demand for ventilation provided by the heating system depends on the inside and outside temperature. Determination of heat demand for heating $Q_{n}$ for the time interval analysed is done with the relation:

$$
Q_{n}=\max (Q(t))[\mathrm{W}]
$$

$Q(t)=$ are the time-varying values of the heat flux in the time interval 9.30-14.00, [W].

The indoor temperature must meet the condition (Constantinescu D., Caracas G., 2014):

$$
\min \left\{\theta_{i}(t)\right\}-12>\Delta \theta
$$

$\theta_{i}(t)=$ indoor temperature at moment $(\mathrm{t}),\left[{ }^{\circ} \mathrm{C}\right]$.

$\Delta \theta=0.5\left[{ }^{\circ} \mathrm{C}\right]$

The condition of air quality as a ventilation rate, correlated with the number of occupants in the amphitheatre is determined with the relation:

$$
n_{a}=32 f(t) \frac{N_{\max }}{V}[\mathrm{sch} / \mathrm{h}]
$$

Number of occupants from amphitheatre, $f(t)$, is determined with the relation (Constantinescu D., Caracas G, 2014):

$$
f(t)=\frac{N_{\text {pers }}(t)}{N_{\max }}
$$

$N_{\text {pers }}(t)=$ number of occupants at moment $(\mathrm{t})$

$N_{\text {max }}=$ maximum number of occupants

$\mathrm{CO}_{2}$. emissions of the occupants in the interval 9.30-14.00 is established by the relation :

$$
\mathrm{D}_{\mathrm{CO}_{2}}=\mathrm{N} \text { pers } * 35 \frac{\mathrm{g}}{\mathrm{h}}
$$

$$
\mathrm{D}_{\text {min fresh air }}=\frac{\mathrm{D}_{\mathrm{CO}_{2}}}{\mathrm{ya}_{\mathrm{a}}-\mathrm{y}_{\mathrm{r}}}\left[\frac{\mathrm{Kg}}{\mathrm{h}}\right]
$$

$y_{a}=\mathrm{CO}_{2}$.admissibleconcentration in the amphitheatre is $3 \frac{\mathrm{g}}{\mathrm{Kg}}$ $y_{r}=\mathrm{CO}_{2}$ admissible concentration of fresh air, $0.75 \frac{\mathrm{g}}{\mathrm{Kg}}$ (bigcity)

\begin{tabular}{|c|c|c|c|c|c|c|c|c|c|}
\hline Time & Volume & $\begin{array}{l}\text { Air Flow } \\
\text { introduced }\end{array}$ & $\begin{array}{l}\text { Surface } \\
\text { of air } \\
\text { intake } \\
\text { grilles }\end{array}$ & $\begin{array}{l}\text { Air } \\
\text { exchange } \\
\text { rate }\end{array}$ & $\begin{array}{l}\text { Fresh Air } \\
\text { flow }\end{array}$ & $\begin{array}{l}\text { No. of } \\
\text { persons } \\
\text { (t) }\end{array}$ & $\begin{array}{l}\text { Maximal } \\
\text { No. of } \\
\text { persons }\end{array}$ & $\begin{array}{l}\text { Air exchange } \\
\text { rate needed } \\
\text { (necessary) }\end{array}$ & $\begin{array}{l}\text { Thermal } \\
\text { load } Q(t)\end{array}$ \\
\hline hour & $\mathrm{mc}$ & $\mathrm{mc} / \mathrm{s}$ & $\mathrm{m}^{2}$ & rate/ hours & mc/hours & pers. & pers. & rate/hours & $\mathrm{W}$ \\
\hline 9:30:00 & 710 & 0.54 & 1.8 & 2.738028 & 1944 & 50 & 120 & 2.253521 & 2643.84 \\
\hline 9:45:00 & 710 & 0.558 & 1.8 & 2.829296 & 2008.8 & 50 & 120 & 2.253521 & 2247.264 \\
\hline 10:00:00 & 710 & 0.576 & 1.8 & 2.920563 & 2073.6 & 50 & 120 & 2.253521 & 2379.456 \\
\hline 10:15:00 & 710 & 0.558 & 1.8 & 2.829296 & 2008.8 & 50 & 120 & 2.253521 & 2445.552 \\
\hline 10:30:00 & 710 & 0.54 & 1.8 & 2.738028 & 1944 & 50 & 120 & 2.253521 & 2511.648 \\
\hline 10:45:00 & 710 & 0.558 & 1.8 & 2.829296 & 2008.8 & 50 & 120 & 2.253521 & 2577.744 \\
\hline 11:00:00 & 710 & 0.576 & 1.8 & 2.920563 & 2073.6 & 50 & 120 & 2.253521 & 2511.648 \\
\hline 11:15:00 & 710 & 0.504 & 1.8 & 2.555493 & 1814.4 & 60 & 120 & 2.704225 & 2577.744 \\
\hline 11:30:00 & 710 & 0.522 & 1.8 & 2.646761 & 1879.2 & 60 & 120 & 2.704225 & 2577.744 \\
\hline 11:45:00 & 710 & 0.54 & 1.8 & 2.738028 & 1944 & 60 & 120 & 2.704225 & 2445.552 \\
\hline 12:00:00 & 710 & 0.522 & 1.8 & 2.646761 & 1879.2 & 60 & 120 & 2.704225 & 2511.648 \\
\hline 12:15:00 & 710 & 0.54 & 1.8 & 2.738028 & 1944 & 60 & 120 & 2.704225 & 2379.456 \\
\hline 12:30:00 & 710 & 0.522 & 1.8 & 2.646761 & 1879.2 & 60 & 120 & 2.704225 & 2445.552 \\
\hline 12:45:00 & 710 & 0.522 & 1.8 & 2.646761 & 1879.2 & 60 & 120 & 2.704225 & 2379.456 \\
\hline 13:00:00 & 710 & 0.54 & 1.8 & 2.738028 & 1944 & 60 & 120 & 2.704225 & 2445.552 \\
\hline 13:15:00 & 710 & 0.558 & 1.8 & 2.829296 & 2008.8 & 70 & 120 & 3.15493 & 2313.36 \\
\hline 13:30:00 & 710 & 0.54 & 1.8 & 2.738028 & 1944 & 70 & 120 & 3.15493 & 2313.36 \\
\hline 13:45:00 & 710 & 0.522 & 1.8 & 2.646761 & 1879.2 & 70 & 120 & 3.15493 & 1916.784 \\
\hline 14:00:00 & 710 & 0.504 & 1.8 & 2.555493 & 1814.4 & 70 & 120 & 3.15493 & 1916.784 \\
\hline
\end{tabular}

For 120 persons we get:

$$
\begin{aligned}
& D_{\mathrm{CO}_{2}}=4200 \frac{\mathrm{g}}{\mathrm{h}} \\
& D_{\text {min } \text { fresh air }}=1866\left[\frac{\mathrm{Kg}}{\mathrm{h}}\right]
\end{aligned}
$$

Table 2. Results - Calculus of fresh air flow, air exchange rate, air exchange rate needed, $Q(t)$ - thermal load 


\section{CONCLUSIONS}

The architectural design of a building which includes a ventilation system influences the technical solution for ventilation.

The natural ventilation for 'A.TALPOSI' amphitheatre presented in this paper was possible due to the difference in hot/cold air density and wind action (influence) and to the architecture of the space.

By our measurements and calculations we have demonstrated the importance and necessity of the control of the number of air exchanges with a view to assuring the thermal comfort in amphitheatres and crowded rooms.

The implementation of a measurement and control system of the necessary air debits does not represent an implementation issue anymore; it is rather an issue of conformity.

In above presentation we calculated the heat load necessary to heat the air taken from outside and transfer it inside the amphitheatre at indoor temperature, activating the natural ventilation.

For the time interval analysed, the maximum heat load for ventilation is $2643 \mathrm{~W}$ that resulted from table no. 2 .

To heat the air taken from outside, we have the possibility to use a heat exchanger in the intake grille with $2643 \mathrm{~W}$ maximum thermal power.

As a result of the experimental data processing, we calculated the air exchange rate (Table 2).

We compared the values obtained with the necessary values. For 60 occupants the air exchange rate is higher than the necessary air rate in the amphitheatre (Table $2, \operatorname{col} 4, \operatorname{col} 8$ ).

When in the amphitheatre there are more than 60 occupants, the air exchanges have values that are less than the necessary values. (Table 2, col 4). In this case, the solution is mechanical ventilation combined with natural ventilation.

For this study, we have demonstrated how necessary it is to assure air exchange with the exterior environment in order to offer the physiologic comfort in inhabited spaces.

Similarly, we have shown that the thermic load for ventilation can be assured depending on the number of occupants, which means a rigorous control of energy consumption for heating.

The spacious classrooms with a big number of occupants might benefit of such a solution for the adjustment of heat for warming up.

By combining the natural ventilation solution with the mechanical ventilation solution, the overall energy consumption for heating are more reduced than in the case when mechanical ventilation only would be used.

\section{REFERENCES}

Busch, J.F., 1992. Comfort in air-conditioned and naturally ventilated offices in Thailand, Energy and Buildings 18 (3-4) 235-249.

N. Bernardi, D.C.C.K. Kowaltowski, 2006. Environmental comfort in school buildings: A case study of awareness and participation of users Environment and Behavior, 38 (2), pp. 155-172.

Chen, Q., 2009. Ventilation performance prediction for buildings: a method overview and recent applications, Building and Environment, 2009, Vol.44, N.4, pp.848 858.

Catalina, T., \& Iordache, V., 2012. IEQ assessment on schools in the design stage. Building andEnvironment, 49, 129-140.

Constantinescu D. Caracaș G., 2014. Analizarea regimului higrotermic și determinarea necesarului de căldură de calcul al cladirilor rar încalzite (Analyzing the hygrothermal regime and determining the heating heat exchanger of the buildings that are rare heated). Conferința Instalații pentru construcții și economia de energie, Iasi 3-4 iulie 2014, 42-61.

D.A. Coley, R. Greeves, B.K. Saxby, 2007. The effect of low ventilation rates on the cognitive function of a primary school class International Journal of Ventilation, 6 (2), pp. 107-112.

Dascalaki E., Santamouris M. et. al., 1995. Predicting Single Sided Natural Ventilation Rates in Buildings, Solar Energy, Vol. 55, No.5, pp.327 341.

E.G. Dascalaki, V.G. Sermpetzoglou, 2011. Energy performance and indoor environmental quality in Hellenic schools Energy and Buildings, 43 (2), pp. 718-727.

Energy Information Administration, 1995. State Energy Data Report 1995, Tables 3 through 7, ldura.

EN 7730 ISO, 2005. Moderate Thermal Environment Determination of the PMV and PPD Indices and Specification of the Conditions for Thermal Comfort, International Organization for Standardization, Geneva.

Huang, Y. C., Chu, C. L., Lee, S. N. C., Lan, S. J., Hsieh, C. H., \&Hsieh, Y. P., 2013. Building users' perceptions of importance of indoor environmental quality in long-term care facilities. Building and Environment, 67, 224-230.

Sarbu, I., \& Sebarchievici, C., 2013. Aspects of indoor environmental quality assessment in buildings. Energy and buildings, 60, 410-419. 
M. Santamouris, A. Synnefa, M. Asssimakopoulos, I. Livada, K Pavlou, M. Papaglastra, et al., 2008. Experimental investigation of the air flow and indoor carbon dioxide concentration in classrooms with intermittent natural ventilation Energy and Buildings, 40 (10), pp. 1833-1843.

Toftum J., 2010. Central automatic control or distribute the occupant control for better indoor environment quality in the future. Building and environment, 45(1), 23-28. 